\title{
STATE POLICY OF SOUTH OSSETIA DURING THE RESTORATION OF AGRICULTURE IN 1920-1930 ${ }^{1}$
}

\author{
(C) Irina K. Dzhioeva, Lira K. Gurieva, Albert V. Techov
}

\author{
South Ossetian State University, Tskhinval, \\ The Republic of South Ossetia; \\ North Ossetian State University, Vladikavkaz, Russian Federation \\ djioeva_irina@mail.ru,443879@mail.ru, albert.texov@mail.ru
}

The article is devoted to the study of the unique historical experience of agricultural development in South Ossetia during the implementation of the new economic policy of 1920-1930. The authors focus on the problems of collective farm construction and agricultural cooperation in South Ossetia, as well as new mechanisms of state management in the agricultural sector of the economy during the study period. It is shown that since agriculture was not directly subordinated to the state by 1920 , it was very difficult to coordinate the labor and economic activities of peasant farms, as well as to manage their innovative development; in addition, the situation was extreme and did not allow the use of administrative methods of management. The only thing that the state could afford during this period was to increase the efficiency of management of this industry by economic methods. Thus, there were new incentives for peasant farms to expand the volume of commodity production. As a rule, the agrarian-industrial transformation corresponds to the free market, especially in agriculture, but this was not typical for Russia attempts at market transformations in the agricultural sector were stopped for the first time by the revolution of 1917. As for the new economic policy, it was an effective market regulator that takes into account the current economic situation in the country, in particular, in the period under study- the reluctance of farmers to sell grain below the market price, and buy essential goods at prices several times higher above their cost, which in any reforms severely limits the amount of savings. In this situation, people only try to consume, not invest, because of distrust of the financial policy of the state. Using the successful experience of agricultural reforms during the NEP period can help solve the problems of sustainable rural development in South Ossetia in the XXI century.

Key words: South Ossetia; agricultural reform; collective farm-state farm system; personal household plots.

\section{[И.К. Джиоева, Л.К. Гуриева, А.В. Техов Государственная политика Южной Осетии в период восстановления сельского хозяйства в 1920-1930 гг.]}

Статья посвящена исследованию уникального по историческим масштабам XX века опыта развития сельского хозяйства в Южной Осетии в период реализации новой экономической политики 1920-1930 гг. Основное внимание уделяется проблемам колхозного строительства и кооперации сельского хозяйства в Южной Осетии, а также новым механизмам государственного управления в аграрном секторе экономики за исследуемый период. Показано, что поскольку сельское хозяйство к 1920 г. не подчинялось напрямую государству, координировать трудовую и экономическую деятельность крестьянских хозяйств, а также руководить их инновационным развитием было очень сложно; помимо этого, ситуация была экстремальной и не позволяла применять административные методы руководства. Единственное, что могло себе позволить государство в этот период - это экономическими методами повышать эффеектвность управления этой отраслью. Так возникали новые стимулы для крестьянских хозяйств в расширения объема товарного производства. Как правило, аграрноиндустриальная трансформация соответствует свободному рынку, особенно в сельском хозяйстве, но для России это не было свойственно, попытки рыночных преобразований в аграрном секторе были пресечены в первый раз революцией 1917 года. Что касается новой экономической политики, то это

1 The article was funded by The Russian Humanitarian Science Foundation, project number 20-51007003 of the Ministry of Education and Science of the Republic of South Ossetia, "Development of the agricultural sector as a factor in improving the standard of living and migration attractiveness of the Republic of South Ossetia." 
был эффрективный регулятор рынка, который учитывает существующее экономическое положение в стране, в частности, нежелание крестьян продавать зерно ниже рыночной цены, а товары первой необходимости покупать в разы выше их себестоимости, что при любых реформах сильно ограничивает размеры накопления. В такой ситуации люди пытаются только потреблять, а не инвестировать из-за недоверия к финансовой политике государства. Использование успешного опыта реформ сельского хозяйства в период НЭП может способствовать решению проблем устойчивого развития сельской местности в Южной Осетии в XXI веке.

Ключевые слова: сельское хозяйство Южной Осетии; рыночные преобразования; новая эконмическая политика; эффективность управления.

Irina K. Dzhioeva - Ph.D. in Economics, Associate Professor, South Ossetian State University, Tskhinval, Republic of South Ossetia.

Lira K. Gurieva - Ph.D. (Advanced Doctorate) in Economics, Professor, North Ossetian State University, Vladikavkaz, Russian Federation.

Albert V. Techov - Ph.D. in Economics, Associate Professor, South Ossetian State University, Tskhinval, Republic of South Ossetia.

Джиоева Ирина Константиновна - кандидат экономических наук, доцент, Юго-Осетинский государственный университет, г. Цхинвал, Республика Южная Осетия.

Гуриева Лира Константиновна - доктор экономических наук, профессор, Северо-Осетинский государственный университет, г. Владикавказ, Российская Федерация.

Техов Альберт Васильевич - кандидат экономических наук, доцент, Юго-Осетинский государственный университет, г. Цхинвал, Республика Южная Осетия.

The policy of "war communism" began to take shape in Russia already during the civil war of the $20^{\text {th }}$ century. Its economic inefficiency, scientific lack of thought and complete failure forced for a certain period to interrupt this peculiar method of management and make a transition to a new economic policy, which contributed to the maximum use of the economic incentives of the Soviet transformation period. As a rule, the agrarian-industrial transformation corresponds to a free market, especially in agriculture, but this was not typical for Russia; attempts at market reforms in the agrarian sector were thwarted for the first time by the revolution of 1917, and the second time after the curtailment of the New Economic Policy (NEP). Peasant resourcefulness, enterprise, skills were practically not used here.

One cannot but agree with the opinion of scientists: V. Danilov, R. Manning, L. Viola that the consequences of the tragedy of the Soviet countryside should be explained by the fact that for two or three centuries Russia was doomed to catch-up development, which was growing as the density population, exacerbation of the struggle for resources. In addition, as these authors rightly believe, the world wars for the redivision of the world in the 20th century inflicted the hardest blow on Russia. The entire burden of losses and problems after each war fell on the shoulders of the peasants as the bulk of the country's population [11].

In her work "State and Economy" Bystrova I.D. notes how one of the young Bolsheviks, at the VIII Congress of Soviets in 1920, put forward the idea of "planned" sowing. This proposal was supported by the party leadership, but it was implemented decades later with the help of political instruments of Stalinist collectivization, during which, according to the author, one of the main directions of the policy and tactics of the ruling party manifested itself - the dominance of the political component over economic forecasting [1].

During the period under study, the restoration of agriculture was a paramount task, without which it was impossible to develop industry. Analyzing the directions of development of the tax system in the period under study, one cannot fail to notice that they led to an increase in the norms of alienation of labor, a lack of interest in the quantity and quality 
of products. In the post-war years, economically developed farms were transferred to the tax obligations of farms, which they never fulfilled. With the constant increase in the volume of work performed by MTS (Machine and Tractor Station), the prices of their services were constantly increasing, which also laid a heavy burden on grain farms. The increase in income tax also had a negative impact on the economy. To force peasants to work on collective farms, they began to reduce the area of personal plots, in addition, they increased the rates of agricultural taxes on personal subsidiary plots. As a result, there was a decrease in the tax base and the amount of tax revenues to the state budget. In order to soften such a blow to the country's economy, agricultural tax rates were increased.

One of the most important measures of the Soviet government in Georgia, which contributed to the restoration and development of agriculture, was decree No. 17 of April 6, 1921 on the nationalization of the land, according to which all land was declared state, or universal national property [9]. In accordance with this decree, the number of small farms both in Russia and in Georgia increased quite significantly, since almost all land-poor peasants and farm laborers were provided with allotments of land after the liquidation of landlord ownership. According to the research of the famous Georgian scientist D. Koridze [2, p. 143] for the period 1921-1927 in Georgia, the number of farms increased from 321 thousand to 414 thousand units, but at the same time, given the fact that it was difficult to cultivate small land plots with agricultural machinery, only 100 tractors worked in the whole republic, primitive agricultural implements had to be used, the situation became more difficult the fact that most of the peasants did not have draft animals, which contributed to a decrease in labor productivity and low yields.

The policy of industrialization contributed to the progressive development of the entire economy of the USSR, where already in 1927 the main indicators of the economy exceeded the level of 1913. The socialist sector of the economy was developing very actively, its share in 1927 was 86\%, and Georgia was no exception, whose industrial output in 1927 amounted to 74.3 million rubles. There was an increase in cooperative production, but there were certain problems in agriculture, although the total agricultural production in Georgia exceeded the level of 1913, but such industries as the production of grain crops and a number of other agricultural sectors lagged significantly.

According to most authors studying the period of collectivization of agriculture in the Soviet Union, the funds for industrialization were acquired through the ruthless robbery of the peasantry by unreasonably lowering the purchase prices for agricultural products through the underestimation of other types of income of the population working in rural areas.

In addition, a huge flow of peasants who moved to the city provided industrialization with cheap labor. Due to the shortage of goods, a mechanism for the excess of demand over supply arose, and with unchanged retail prices, latent inflation arose, free money through savings banks was used by the state. According to the 1917 census in South Ossetia, 10,099 peasant farms had 23,588 tithes, or $58 \%$ of convenient land. One farm had only 2.2 tithes of land [3, p. 322].

By the time of the establishment of Soviet power - the Soviet Union was formed on December 30, 1922 - in South Ossetia, the region's economy as a whole was characterized by excessive backwardness. The main production tools were a plow, a hoe, a wooden plow and a harrow. In 1923, according to the agricultural census, in peasant farms in Georgia there were (in thousands of units): plows -63.0 , wooden plows -7.4 , iron plows 1.78, wooden harrows -54.8 and iron harrows - 3.0. In South Ossetia itself, which was part of Georgia, there were only 10,099 peasant farms, which had 23,588 tithes or $58 \%$ of convenient land. One farm had only 2.2 acres of land [1, p. 322]. Iron arable tools to their total number accounted for only $9 \%$. The number of farms without arable implements 
reached 54\%, and without transport equipment $60 \%$ [7, p. 52]. Of the 12651 farms in South Ossetia, 27\% were without arable implements, and 50.2\% were without arable implements. Iron arable tools accounted for only 3.5\% of the total number of agricultural tools [6, p. 256].

To carry out land reform in South Ossetia in 1923, 86 land committees were organized, which carried out work on the registration and distribution of the confiscated land of landowners among the peasants.

As a result of the land reform, 1526 tithes of arable land, 50 tithes of orchards and vineyards were confiscated from 19 landowners, of which all 1526 tithes of arable land and 7 tithes of orchards were transferred to landless and land-poor peasants. Thus, 1796 households with a population of 12.5 thousand people were satisfied with the land. The remaining 43 tithes of orchards and vineyards were left for the organization of cultural demonstration farms at the People's Commissariat of Agriculture of South Ossetia. But this amount of land was not enough, because in 1923, as a result of severe landslides, a large number of peasants were deprived of their previously owned plots. In this regard, it became necessary to accurately record all land areas, and from the surplus found to form a resettlement fund. In parallel with this, it was planned to gradually relocate landless peasants to these lands [6, p. 202].

Table 1. Dynamics of agricultural land in South Ossetia in 1921-1927 (tithes)

\begin{tabular}{|l|c|c|c|c|c|c|}
\hline Years & Arable land & Gardens & Vineyards & Hayfields & Lands & $\begin{array}{c}\text { Vegetable } \\
\text { gardens }\end{array}$ \\
\hline 1921 & 4211 & 130 & 150 & 500 & 500 & 30 \\
\hline 1922 & 8643 & 135 & 160 & 1274 & 550 & 40 \\
\hline 1923 & 15288 & 138 & 195 & 1556 & 572 & 50 \\
\hline 1924 & 18784 & 195 & 315 & 2111 & 572 & 58 \\
\hline 1925 & 20155 & 187 & 226 & 2425 & 560 & 86 \\
\hline 1926 & 23102 & 199 & 298 & 3289 & 576 & 108 \\
\hline 1927 & 46900 & 299 & 379 & 3289 & 625 & 113 \\
\hline
\end{tabular}

The table is compiled for the restoration and development of the national economy of South Ossetia. Collection of documents and materials (1921-1929). Volume 1 p. 256.

In accordance with the statistical data, it can be determined that the dominant position in the agriculture of South Ossetia is field cultivation and livestock breeding closely related to it.

Field cultivation in the region was carried out mainly in the foothill and plain zones. In the mountainous area, due to the difficult climatic conditions, only vegetables were grown for their own consumption. In the study period, there was a deficit of grain crops up to $35 \%$, and it was replenished at the expense of other regions. This was due to the lack of 
land and irrational economy management, in particular: sowing the same crops for a long time in the same area, ineffective tillage, sowing unsorted seeds, lack of fertilizers [6, p. 291].

As for the availability of tools for agriculture at the beginning of the recovery period, it was extremely insufficient, and it was absolutely primitive. Agricultural implements began to be allocated to peasants on preferential terms since 1924. These were iron plows, harrows, winnowers, triers, hand mills, corn crushers, etc.

We consider the following archival material, which concerns the quality of products, to be quite relevant: "[...] the advantages of plows manufactured by Selmash, the AllRussian syndicate of agricultural machinery, were quickly taken into account. These plows turned out to be of a higher quality than foreign ones. And at a price of 16 rubles cheaper, which for the peasant plays a big role in his meager budget. The demand for overseas plows fell sharply. In the reporting year, 47 plows of the Eckert brand of a foreign company and 127 Russian plows were sold, the demand for which is growing every day" [6, p. 247].

In South Ossetia, such an important branch of agriculture as vegetable growing lagged behind, and the demand for the production of vegetables grew, since, with the development of industry, the number of the urban population began to increase. And, since 1921, there has been a gradual increase in the area under vegetable crops. In 1921, the area for vegetable crops in the entire region was only 30 hectares, and in 1925 it had already reached 113 hectares or increased by 3.7 times. This growth of vegetables was initiated by the organization of the first state farms in Akhalogor, Tskhinvali and Java. In 1928, in these state farms it was planned to sow vegetable crops on an area of 22 tithes, including 14 tithes in the Akhalgori state farm, 6 tithes in Tskhinvali and 2 tithes in the Java state farm. These crops were initially indicative and agitational. They were visited by peasants and collective farmers of newly organized collective farms with the aim of acquainting and exchanging experience in the cultivation of vegetable crops. In this regard, the most organized was the vegetable farming of the Tskhinvali state farm, the sown areas of which were located on the territory of the present-day city of Tskhinval and occupied its western part. In the spring, the population could buy here seedlings of tomato, cabbage and other vegetable crops, which were grown in the greenhouses of this state farm [4, p. 345]. Despite the shortcomings, the collective farms in the pre-war period made a significant contribution to the development of agriculture in the region [5, p. 88].

As a result of the Menshevik riots, the area under crop in South Ossetia after 1917 decreased by $31.6 \%$. In the future, the it began to increase and by 1939 they were doubled.

Table 2. Area under crop of South Ossetia for the period 1917-1939 (ha)

\begin{tabular}{|c|c|c|}
\hline Years & Area under crop & 1939 as a \% by 1917 \\
\hline 1917 & 19000 & 100,0 \\
\hline 1921 & 13000 & 68,4 \\
\hline 1931 & 32577 & 171,4 \\
\hline
\end{tabular}


Научный альманах стран Причерноморья. 2020. Том 23. № 3

\begin{tabular}{|l|c|c|}
\hline 1933 & 35000 & 184,2 \\
\hline 1937 & 36690 & 193,1 \\
\hline 1939 & 393776 & 209,3 \\
\hline
\end{tabular}

The table was compiled according to V.D. Abaev. Economic development of South Ossetia. Part 3. p. 88.

Due to land scarcity in the very first years of Soviet power, the Georgian government was forced to allocate land plots in the Gori region for the population of South Ossetia.

Significant changes have taken place in the needy strata of the peasantry and in the provision of livestock. In 1923, according to the census, the number of farms without any livestock was $14.3 \%$, and in 1929 it was already $6.7 \%$. The number of farms without draft animals also decreased from $31.2 \%$ to $11.5 \%$, and the number of dairy cattle from 44 to 24.7 [10, pp. 120-121].

It should be noted that this most important branch of agriculture was backward and did not contribute to the development of the country's national economy. In the period 1929-1933. there is a decrease in the number of livestock. Almost all the authors whose works we studied in the course of the research claim that the kulak agitation for the slaughter of cattle, which had fertile soil during the years of complete collectivization, is to blame, and this situation was observed in all regions of the country. By 1940, this situation improved to some extent, and compared to 1930 , the total livestock population increased by more than 19 thousand heads [5, p. 368].

Considering these historical events from the standpoint of the modern time period, one can give them another explanation. The peasants did not want to go to collective farms; most of them were hard-pressed to violent agitation and threats. Transfer your livestock to public property i.e. they did not want to go to collective farms and put up every possible resistance to universal collectivization, burned collective farm property, destroyed livestock, of course, these were the costs of collectivization, but the costs were also the fact that the livestock that was transferred to collective farm use most often died due to lack of proper care.

In the archives of South Ossetia there is no data on the percentage of kulaks, middle peasants and poor peasants, there is also no data on the deliberate destruction of livestock, on the opposition of peasants to the Soviet regime. This can be explained by the fact that there was no big differentiation in the income of the rural population, since after the Menshevik pogrom of 1920 everything had to be lifted from the ruins and almost the entire population was in the same distress, and only with the advent of Soviet power in South Ossetia did it become possible to raise the standard of living population.

From the archival data and the study of scientific works of scientists studying this period, it follows that by April 1923 the peasants of South Ossetia were given 1,096 tithes of arable land. The first agricultural partnerships organized by this time showed the advantage of collective farming through the use of agricultural machines and new methods of labor.

However, due to the poor harvest in 1921-1922, which covered almost the entire country, South Ossetia, due to the implemented institutional reforms and the radical mod- 
ernization of agricultural production, managed to cope with the difficulties and get out of the food crisis [6, p. 6].

To combat hunger, in February 1922, the South Ossetian Regional Committee for Aid to Famine was organized, which had its branches in the districts and villages. Through this network, state aid was provided to the starving with money, seeds and food grains [6, c.272]. Subsequently, peasant committees of public mutual assistance were created, which existed until the period of collectivization of agriculture. There were over 10 peasant committees in the districts; their activities were directed by the regional peasant committee, which was located in the city of Tskhinval. Peasant committees in South Ossetia worked to restore the destroyed economy, provided assistance to the poor and, especially, to the emerging cooperative organizations.

Based on the results of the study, the following conclusions can be drawn:

1. Errors in government management during the period of War Communism, the illconceived process of conducting food appropriation in rural areas caused discontent among the entire population of the country, which forced the Bolshevik government to switch to a new economic policy, which at that time was more flexible and combined various forms of ownership.

2. In South Ossetia, agriculture in the recovery period, as before, tended to develop on the basis of small peasant farms, but the attitude to property changed radically, since the land was nationalized and transferred to the ownership of peasants, and, therefore, withdrawn from commodity circulation.

3. The historical analysis of the results of the new economic policy allows us to conclude that it is possible to take them into account for the sustainable development of the agricultural sector of the South Ossetian economy in the near future, since in modern conditions the effective use of market incentives in combination with state regulation of agriculture can contribute to the rapid development of the agricultural sector of the economy. , become a factor in improving the living standards of the country's population and contribute to the growth of the migration attractiveness of the Republic of South Ossetia [1]. This requires not only technological, market and product innovations (introduction of new agricultural production technologies, growing new agricultural products, entering new external markets), but also the use of new methods of organizing the management of rural areas.

\section{Лumepamypa}

1. Быстрова И.Д. Государство и экономика [Электронный ресурc]. URL: http://www.fedy-diary.ru/library-pages/auditorium-n-f-bugaj-20-50-e-godypereseleniya-i-deportacii-evrejskogo-naseleniya-v-sssr/i-v-bystrova-gosudarstvo-iekonomika-v-1920-e-gody-borba-idej-i-realnost/ (Дата обращения: 28.04.2020).

2. Коридзе Д. Национализация земли в Советской Грузии // Труды института экономики АН ГССР. Тбилиси, 1949. С.171-178.

3. Ванеев 3.Н. Крестьянский вопрос и крестьянское движение в Юго-Осетии. Сталинир, 1959. 322 с.

4. Техов В.С. Сельское хозяйство Южной Осетии в послереволюционный восстановительный период и в период коллективизации // Известия ЮгоОсетинского научно-исследовательского института. Вып. XL. С. 331-377. 
5. Абаев В.Д. Экономическое развитие Юго-Осетии. В 3 ч. Ч. З. Госиздат ЮгоОсетии: Сталинир, 1965. 158 с.

6. Восстановление и развитие народного хозяйства Юго-Осетии. Сборник документов и материалов (1921-1929 гг.). Т. 1. с. 256

7. Грузинская ССР за 20 лет // Сборник документов и материалов. Тбилиси, 1941. $152 \mathrm{c}$.

8. Гуриева Л.К. Эволюция теории инновационного развития экономики: основные подходы и концепции. Владикавказ, 2005.

9. Декрет Ревкома Грузинской ССР о национализации земли от 6 апреля 1921г. [Электронный ресурc]. URL: http://docs.historyrussia.org/ru/nodes/134532 (Дата обращения: 8.05.2020)

10. Советская Грузия в цифрах. Сборник документов и материалов. Тифлис, 1927. $-189 \mathrm{c}$.

11. Трагедия советской деревни. Коллективизация и раскулачивание. 1927- 1939. Документы и материалы. В 5-ти тт. / Под ред. В. Данилова, Р. Маннинг, Л. Виолы. М.: «Российская политическая энциклопедия» (РОССПЭН),1999-2006. [Электронный ресурс]. Режим доступа: http://tragedia-sovetskoy-derevni1.blogspot.com/2008/09/1.html (Дата обращения: 2.05.2020)

\section{References}

1. Bystrova I.D. Gosudarstvo i ekonomika. [State and economy]. Available at: http://www.fedy-diary.ru/library-pages/auditorium-n-f-bugaj-20-50-e-godypereseleniya-i-deportacii-evrejskogo-naseleniya-v-sssr/i-v-bystrova-gosudarstvo-iekonomika-v-1920-e-gody-borba-idej-i-realnost/, free (accessed: 28.04.2020) (In Russian).

2. Koridze D. Natsionalizatsiya zemli v Sovetskoy Gruzii [Nationalization of land in Soviet Georgia]. Trudy instituta ekonomiki AN GSSR. Tbilisi, 1949. pp.171-178 (In Russian).

3. Vaneyev Z.N. Krestyanskiy vopros i krestyanskoye dvizheniye v Yugo-Osetii [The peasant question and the peasant movement in South Ossetia]. Stalinir, 1959. 322 p. (In Russian).

4. Tekhov V.S. Selskoye khozyaystvo Yuzhnoy Osetii v poslerevolyutsionnyy vosstanovitel'nyy period i v period kollektivizatsii [Agriculture of South Ossetia in the postrevolutionary recovery period and in the period of collectivization]. Izvestiya YugoOsetinskogo nauchno-issledovatelskogo instituta. Is. XL. pp. 331-377(In Russian).

5. Abayev V.D. Ekonomicheskoye razvitiye Yugo-Osetii [Economic development of South Ossetia]. V. 3. Gosizdat Yugo-Osetii: Stalinir, 1965. 158 p. (In Russian).

6. Vosstanovleniye i razvitiye narodnogo khozyaystva Yugo-Osetii. Sbornik dokumentov i materialov (1921-1929 gg.) [Restoration and development of the national economy of South Ossetia. Collection of documents and materials (1921-1929)]. V. 1. p. 256 (In Russian).

7. Gruzinskaya SSR za 20 let. Sbornik dokumentov i materialov. [Georgian SSR for 20 years. Collection of documents and materials]. Tbilisi, 1941. 152 p. (In Russian).

8. Guriyeva L.K. Evolyutsiya teorii innovatsionnogo razvitiya ekonomiki: osnovnyye podkhody i kontseptsii [Evolution of the theory of innovative development of the economy: basic approaches and concepts]. Vladikavkaz, 2005 (In Russian). 
9. Dekret Revkoma Gruzinskoy SSR o natsionalizatsii zemli ot 6 aprelya 1921g. [Decree of the Revolutionary Committee of the Georgian SSR on the nationalization of land from April 6, 1921]. Available at: http://docs.historyrussia.org/ru/nodes/, free (accessed: 8.05.2020) (In Russian).

10. Sovetskaya Gruziya v tsifrakh. Sbornik dokumentov i materialov [Soviet Georgia in numbers. Collection of documents and materials]. Tiflis, 1927. 189 p. (In Russian).

11. Tragediya sovetskoy derevni. Kollektivizatsiya i raskulachivaniye. 1927- 1939. Dokumenty i materialy. [The tragedy of the Soviet village. Collectivization and dispossession. 1927-1939. Documents and materials]. Moscow: «Rossiyskaya politicheskaya entsiklopediya» (ROSSPEN),1999-2006. Available at: http://tragedia-sovetskoy-derevni-1.blogspot.com/2008/09/1.html, free (accessed: 2.05.2020) (In Russian). 